J. Dairy Sci. 94:536-536

doi:10.3168/jds.2011-94-1-536

(c) American Dairy Science Association ${ }^{\circledR}, 2011$.

\title{
Erratum to "Effects of a molasses-coated cottonseed product on diet digestibility, performance, and milk fatty acid profile of lactating dairy cattle" (J. Dairy Sci. 93:3128-3135)
}

\section{R. Mullins and B. J. Bradford}

An error was made in the reported feeding rate of the direct-fed microbial (DFM) in this paper. On page 3129 (Design and Treatments section, right column), the fourth sentence of the paragraph should read (correction in boldface): "The DFM was an extract of $A$. oryzae (Amaferm, BioZyme Enterprises Inc., St. Joseph, $\mathrm{MO})$ and was fed at a rate of $\mathbf{1 0} \mathrm{g} /$ cow per d."
In Table 1 (page 3130), the inclusion rate for the DFM in the LC+DFM diet should be $\mathbf{0 . 0 1 \%}$.

The authors regret this error.

Mullins, C. R., and B. J. Bradford. 2010. Effects of a molasses-coated cottonseed product on diet digestibility, performance, and milk fatty acid profile of lactating dairy cattle. J. Dairy Sci. 93(7):31283135 . 